\title{
A Study of the Reflection of Naturalism in the Heroine in Sister Carrie
}

\author{
Xiu Zeng \\ Foreign Language School, Nanchang Normal University, Nanchang, Jiangxi, China
}

\begin{abstract}
Sister Carrie is one of the greatest works composed by Theodore Dreiser, one of the representatives of naturalists in American literature at the beginning of the 20th century. Among numerous works of Theodore Dreiser, Sister Carrie enjoys a quite high literary status, and also meets with different comments after its publication. The novel mainly tells the personal experiences of a rural beautiful girl Carrie in the big city Chicago. Driven by natural desires and urban environment, she changes her social status and original values in the end. Naturalism is a scientific and literary approach employed here to depict the characters in the novel where a person's fate is decided or predetermined by impersonal forces of nature and environment beyond human control. The novel is an experiment where the author could discover and analyze the natural forces and survival laws that influence personal behaviors, emotion and fate. This paper introduces the origin, development and characteristics of naturalism in American literature, studies the effect of human weakness on their life, and makes clear the influences of environment on people's way of thinking and way of life.
\end{abstract}

Index Terms—naturalism, Sister Carrie, human weakness, environment

\section{INTRODUCTION}

Sister Carrie is one of the great naturalistic novels of the American realistic writer Theodore Dreiser. The novel tells a story of a pure and beautiful country girl Carrie, who goes up social ladder from the bottom line of society to a recognized one, a Broadway star. In the process where Carrie pursues her dream, she has gone through the hardship of job hunting, diseases, unemployment until an accident puts her to fame and wealth. In the novel Dreiser points out the influences of human weakness and environment on the girl and her fate. The novel has a distinctive naturalism style. It can be seen that Carrie, by nature, is a pure, timid and innocent girl, it is nature that has formed Carrie. She entrusts herself first to one man, then to another out of desire for a better material life. She is like a leaf carried by wind, lucky enough, she follows a right direction in the pursuit of the American Dream. In-born vanity, desire for wealth and fame and hard living circumstance drive her to reach her goals. But she is lonely even when she gets what she has dreamed, she does not know what is true happiness in her endless pursuit, she is a victim of her own desire.

In the late $19^{\text {th }}$ and early $20^{\text {th }}$ century, the Unite States went through a profound change in economic development, industrialization and urbanization. A rich variety of commodity was provided and people were encouraged to compete with each other to purchase and show off their newly-bought goods: the rich built mansions and bought expensive clothes; girls were main stream of consumers of luxurious goods; men were proud of attracting and occupying beautiful women. Driven by fashion and inner desire, surrounded by colourful advertisements and articles, and trying to show her own value and importance, at last Carrie could not help but follow suit, in this sense, she is a victim of environment.

A brief introduction to the author Dreiser helps to read and understand the novel better. Dreiser was born in a large, poor, immigrant family at Terre Haute, Indiana in 1871. He had his childhood in bitter poverty, lacking enough education, job skill and social status. His family moved from house to house followed closely by poverty, insecurity and internal division. He hoped to realize his dreams when he went to Chicago at the age of 15. In Chicago, he did a lot of odd jobs for a very low wage in different places, it was hard to earn a living for him. Dreiser went to all the major cities in the United States as a reporter at 23, he witnessed the hard life of people who struggled in low class, in the meantime, he saw a luxurious life of the rich. Dreiser's early experiences destroyed his fantasy, he gradually realized that ethics was a luxury for the poor. Dreiser's own bitter experiences of poverty as a youth and his early yearnings for wealth and success would become dominant themes in his novels. In 1900, the first novel Sister Carrie was published, followed by Jennie Gerhard in 1911. As a naturalistic writer, Dreiser stressed determinism in his characters in his novels. His characters cannot assert their will against natural and economic forces. Dreiser held that people were not entirely to blame for what they were and what they did, for they were not under the control of their own will.

\section{AN INTRODUCTION TO NATURALISM}

Naturalism is a kind of new critical realism developed under the war and social turmoil which affects people's beliefs in their early ages. It is known that naturalism came from Europe, and was first put forward by the French novelist Emile Zola, who held that the purpose of a novelist was to be a scientist, to place his characters in a situation and then to watch the influences of heredity and environment on them(Ye,2013). This idea was picked up by writers in different countries, they held that realism was too genteel in tone to reveal the harsh reality, then a literary movement called 
"Naturalism" started. Naturalism in America had been shaped by the war, by the social upheavals that undermined the comforting faith of an earlier age, and by the disturbing teachings of Charles Darwin. Darwinism seemed to stress the nature of animal in man, to suggest that man was dominated by the irresistible forces of evolution (Wu, 2005)). In reflecting the reality of life, naturalistic writers tended to show the feature of sentimentalism of early romanticism (Wu, 2005). The difference between naturalism and romanticism is that naturalists take the attitude that the world is lack of morality, people have no willing of freedom, their lives are controlled by heredity and environment (Wu, 2005), people lead a miserable life when they are alive, but they are forgotten by others after they are dead. Though naturalism reveals the weakness of the world by the way of extremely strict realistic technique, it sometimes paves the way to improve the world by social reform (Wu, 2005 ).

With the development of economy, science and culture, influenced by European naturalistic literature, American naturalistic literature emerged in the late $19^{\text {th }}$ century and the major representatives were Stephen Crane, Jack London, Frank Norris and Theodore Dreiser etc. These writers' detailed depiction of the lives of the miserable and the abnormal, their frank treatment of human passion and sexuality, and their portrayal of man and women overpowered by blind forces of nature still exert a powerful influence on modern American literature (Wu, 2005 ).

The main characteristics of American naturalism can be outlined as follows: First of all, naturalists put more emphasis on details, trying to present life as real and clear as possible, keeping true and loyal to the harsh reality and even going to the extreme to show the harsh and inhuman truth. Second, the characters naturalistic writers portrayed in their novels were usually from the lower class, whose destiny was restricted by environment and heredity (Wu, 2005). The characters were driven by basic needs, such as hunger, fear and sex. Therefore, Naturalists took the moral attitude for all human behaviors, no blame and no praise. Third, naturalists made use of simple and sometimes "strong" words to describe the crude lives of the poor. Finally, pessimism and deterministic ideas of naturalism pervaded the works of such writers as Stephen Crane, Jack London and Frank Norris, Henry Adams and Theodore Dreiser etc, they believed that the world was amoral, that the destiny of humanity was misery in life and oblivion in death (Wu, 2005).

\section{THE EFFECT OF HuMAN WeAKNESS ON THE HEROINE}

Naturalists believe that human beings, under the blind forces of their nature, can not control themselves in making sound judgement and right decisions. Just like animals, their behaviour is largely determined by the inner passion and desire, not by reason or logic, this is clearly reflected in the heroine Carrie and in the other characters as well in the novel. The following will act as proof to show the effect of human inner desires on the life experience of the heroine Carrie.

\section{A. Carrie's Hunger for Comforts}

Carrie was a rural and simple girl from a low class in the remote countryside, she did not get much into touch with modern enlightenment. "Books were beyond her interest. In the intuitive graces she was still crude. She could scarcely toss her head gracefully. Her hands were almost ineffectual. The feet, though small, were set flatly. And yet she was interested in her own charms, quick to understand the keener pleasures of life, and ambitious to gain in material things." (Dreiser, 1991). She was often unsatisfied with her living condition there and also her social status. She left home for her father's thin income was not sufficient to buy her pretty clothes and provide her with a comfortable life. She dreamed of leaving her home and being a member of an upper class one day, then she could enjoy all of the things that she had desired. On the train, she was expecting of a good life in Chicago, but when she was living at her sister's home in Chicago, she discovered that her life there would be far from the happy, carefree existence, and her dream was broken. To earn herself a living, she had to go job-hunting and got a job in a shoe factory, but lost it because of a bad cold. While she was looking for a job, she met the salesman Drouet again, who could satisfy her with beautiful clothes and enjoyment in life. Just as what is described in the novel "Her advantages and disadvantages she had understood, and also quickly understood the further fun in life there were, she was eager to get material comforts. She was a little knight not equipped with all, but she enlarged her courage to take risks in this mysterious city, doing step beyond the bounds of an empty dream of peace."(Dreiser, 1991). Carrie looked like a knight who was not fully equipped, risked exploring this mysterious city, imaging that she could dominate her life one day in the future.

Perhaps, we cannot simply say that Carrie has no sense of what is right and wrong, it is her desire for comforts that leads her to make choices or decisions in life and in jobs. She leaves the factory for she has got accustomed to the slow, free life in the country, "at home she got up at seven or eight o'clock every morning, and now she must get up at six, and in rural areas, she was free, can go wherever she wants to go"(Dreiser,1991), but now she was bound in the dark factory. Her nature of pursuit of comforts rebels against the strict requirements of the factory and forces her to seek another way of life to satisfy herself.

\section{B. Carrie's Pursuit of Money}

Pursuit of money plays an important role in Carrie's life and drives her to rise from a timid and simple girl all the way to a Broadway star. Even at her early age, she understood the importance of a full pocket, and never stopped struggling for it. When she arrived at Chicago, she was much attracted by many bright clothes, shoes, hats, scarves and high buildings. She felt shabby and a little ashamed of herself in front of the women in fashion and the magnificent city. 
Also she had to pay her sister the hard-earned money as rent, and this even drove her into poverty. She realized that the only way to get rid of poverty was to earn sufficient money so as to assure her survival in big city and then comforts. After that, pursuit of money became a major goal in her life. She agreed to live with Drouet for his financial help, for the some reason, she abandoned Hurstwood because of his bankruptcy in business. Under her inner drive for wealth, Carrie tried hard to look for a job, then luck began to fall on her. She got a job as a chorus girl, then became a well-known actress, and a guest at a local hotel. In the end, she had money and all the comforts and luxuries which appealed to a country girl.

\section{Men's Desire for Beauty}

Dreiser's novels of businessmen often introduce the notion that men of high sexual energy are financially successful, the two businessmen who chased Carrie may not be considered financially successful, but they both had strong sexual desire for beauty. When Drouet first met Carrie in the train to Chicago, he was much drawn to her beauty, but he did not fell into love with Carrie, to him women were like goods displayed in the shop window, "Drouet paid attention to some of the trendy clothing or appearance of beautiful women, on their overcritical in the street." (Dreiser, 1991). Like most men of his age, he took interest in women, in their beauty, in the way women carried themselves, "He saw how they set their little feet, how they carried their chins, with what grace and sinuosity they swung their bodies. A dainty, self -conscious swaying of the hips by a woman was to him as alluring as the glint of red wine to a topper." (Dreiser.1991). He was born with sexual desire, he chased a beautiful woman perhaps to satisfy his curiosity or to meet his sexual desire. Therefore, he would not choose to marry Carrie, he only desired to possess Carrie to satisfy his innate sex desire, to highlight his power and success. For this reason, he felt thrilled that Carrie finally lived together with him .And then, he could not wait to invite his friend Hurstwood to his home to show his power and charm.

It is just the same with Hurstwood, he was almost twice Carrie's age, and was attracted by Carrie's appearance too, for Carrie was so young and beautiful, she could meet his physical and psychological needs. To some degree, Carrie had to thank the two men who had helped her to go through the hard days and then survive in the unfriendly city, but it is through the life with them that Carrie began to understand what money meant to her, and what she had to do to gain a comfortable and luxurious life as she had dreamed.

\section{THE INFLUENCE OF ENVIRONMENT ON THE HEROINE}

Environment is another factor that will certainly produce effects on the life experiences of humans, for no one can survive without exchange or interaction with the things and persons around him, no one can remain the same all the way without being influenced by his living surrounding, Carrie is no exception. Her beliefs and values were greatly changed since she arrived at Chicago, her life experiences were sure to be changed by what happened in America, by what people believed at that time. The following will show the effect of environment on her beliefs and values.

\section{A. Consuming Concept}

The late $19^{\text {th }}$ and the early $20^{\text {th }}$ in America was an age of great prosperity. Increased wealth and desire for its conspicuous display gave rise to a gingerbread era of American design whose prime function was to attract attention $(\mathrm{Wu}, 2005)$. Success in business led to a general growth in wealth and then in consumption, consumption was the most popular thing in the United States at that time. People were encouraged to compete with each other and to show off their wealth. American millionaires built Gothic mansions and decorated them with various ornaments. Rooms of rich men were filled with art imported from Europe, as were the symbols of culture. Wealthy Americans adopted European dress styles and manners. People invested in and built a variety of restaurants, hotels, cafes to make luxurious life easier. Riches began to be taken as a symbol of one's social status, riches were also believed to be in league with virtue. All of these were the examples to show what the consuming concept was like in America at that time. People listened to their instinct, "as consumers will make pleasure as their own obligations, enjoyment and satisfaction as a cause" (Auster, 1984). Consumption became men's main social activities.

In this social circumstance, Carrie could not reject the temptation brought about by highly developed industrialization and commerce, she was eager to follow the fashion, to share those pretty clothes, nice carriages and the like to show her taste and social identity. When Carrie arrived in Chicago and saw an array of merchandise in store, or when a gorgeous woman passed by, she felt important to have these and did not hope to be looked down upon by the rich women while she was still in her shabby clothes. Later on Carrie never gave up an opportunity to be a city consumer, she began to understand that clothes were the tickets to enter the consumption-focused community. Therefore, national prosperity and a new idea of commercial consumption had an effect on Carrie's way of thinking and the way of life.

\section{B. Richness in Commodities}

Dazzling progress in business and industry helped provide a richer variety of commodities such as hats, shoes, dresses and jewelry for people to approach and choose, but they were available to only those rich women, perhaps not to Carrie. In spite of this, those precious items filled her with unbelievable magic, in her eyes, "there is nothing that she need not, there is nothing that she did not want. Exquisite slippers and stockings, beautiful ruffled shirt and skirt, lace, ribbons, combs, wallets, everything affects her personal desires" (Bassham, Ben L, 1978). Carrie had a special longing 
for the exquisite items not only to satisfy her vanity, but also to change her low social standing. The American anthropologist Marshall Sahelisi said "dress is not just a series of objects to wear, but also symbols through which people can know which member of social groups the wearer belongs to, and reveals the existence of genders or social class differences." (Luedtke, Luther S.ed, 2001). Carrie's simple, indecent clothes was an indicator of her low social rank, which Carrie was not willing to accept, it hurt her pride and upset her mentally.

\section{Social Circle}

In Carrie's growth from a pure country girl to a Broadway star, two groups of persons play an important part in it. One group is Mrs. Hale and Mrs. Vance, who introduced Carrie to new wealth, the other group is Drouet and Hurstwood. Mrs. Hale took Carrie to the mansions in Chicago and caused Carrie to expect something a little better than Drouet could afford. Mrs. Vance presented Carrie the Broadway fashion show, then Carrie began to be dissatisfied with her own life and would have an urge to move forward.

Drouet first helped Carrie move out from her sister's home and escape from a life pressed hard by lack of money, then provided Carrie with necessities in life. More than this, Drouet bought Carrie what she was fond of and let her know what the life in Chicago was like, giving her a hope and hunger for a dreamed life in big city. Further, being young and curious, Drouet often got Carrie to start something new and encouraged her to go on with it, for example, Drouet offered Carrie an opportunity to act on the stage where she found an acting talent in herself and grew confident of herself. From then on she believed that she could depend on herself to make money and to be in fashion if she had an opportunity.

While on the other hand, Hurstwood was quite different from Drouet in manner and behaviour. Hurstwood was a man of wisdom and taste. His keen eyes, his good manner, his fine clothes and all things about him were so good in Carrie's eyes that she learned them to improve herself. As a matter of fact, it was through his wealth, status and influence that Carrie rose high in life and on the stage. Besides, he was strong in providing the social context in which Carrie could succeed. Both Drouet and Hurstwood had done much to contribute to Carrie's success as an actress.

Moreover, Carrie's sister Minnie is another person who brings about changes in Carrie's attitude to life. Faced with the hardship in life, living on the bottom line of social ladder, Minnie had to save every hard-earned penny, life to her was actually a matter of endless struggle for a survival. This was a kind of life Carrie was unwilling to endure and accept, so she decided to start her journey to seek a new way of life for herself.

Dreiser stated in this novel "when a girl leaves her home at eighteen, she does one of two things. Either she falls into saving hands and becomes better, or she rapidly assumes the cosmopolitan standard of virtue and becomes worse."(Dreiser.1991). Long exposed to and gradually affected by the cruelty of consumer society, Carrie began to care more about herself and finally decided to leave Hurstwood while he gradually sank to deprivation and suicide. Carrie's "constant move to something better was not to be denied" (Rosenblatt, Roger, 1999), her choice to leave Hurstwood was almost completely motivated by finances. Whether Carrie's life in the cities finally turned her for better or for worse depended much on how she took it morally, but without doubt, after living in city for many years, Carrie was no longer what she had been in the country, city life has changed her into another girl.

\section{CONCLUSION}

From what has been presented above, one can see that the heroine Carrie in Sister Carrie is depicted mainly from the literary approach of naturalism. Naturalism, the harsher realism, helps the reader understand the helplessness of the characters who are the victims of their own weakness (nature) and environment. The central figure Carrie is dominated by her instincts such as desires, needs and fear to search for money, success and sensual gratification on the one hand, and she is influenced by consumerism and her social circle to meet her satisfaction of desires on the other hand. Carrie seemed to end up in success for she gained what she had dreamed, but it was an empty success, for she was still lonely sitting in a rocking chair, she did not understand what was true happiness and true success. Born and growing up in a poor family, Carrie was not taught by her family members to have a right view on wealth. What is worse, a rapid increase in national wealth and a wide spread pursuit of money brought American people a value crisis, they were puzzled, blind by the dazzling wealth of " the Gilded Age" in America, as Mark Twain called, and then got lost.

\section{REFERENCES}

[1] Auster, Albert. (1984). Actresses and Suffragists: Women in the American Theatre, 1890-1920. New York: Praeger Publishers.

[2] Ben L. Bassham. (1978). The Theatrical Photographs of Napoleon Sarony. Kent: The Kent State University Press.

[3] Luedtke, Luther S. ed. (2001). Making America: The Society and Culture of the Unite States. Washington D. C.: Unite States Information Agency.

[4] Rosenblatt, Roger. (1999). Consuming Dreiser: Consumption, and the Pursuit of Happiness. Washington D. C.: Island Press.

[5] Theodore Dreiser. (1991). Sister Carrie: An Authoritative Text, Backgrounds, and Sources Criticism (Norton Critical editions). New York: W.W. Norton \& Company.

[6] Wu weiren. (2005). History and Anthology of American Literature. Beijing: Foreign Language Teaching and Research Press.

[7] Ye shengnian. (2013). Western Culture: An Introduction. Shanghai: Shanghai Foreign Language Education Press. 
Xiu Zeng is an English teacher in Foreign Language School, Nanchang Normal University, Nanchang, Jiangxi, China. She has received her M.A in English language and literature from Jiangxi University (Nanchang University thus named today), her main interest is in English teaching, English and America literature instructing. 